\section{Paul Béré S.J.}

Pontificio Istituto Biblico / Roma (Italia)

barkwennaam@gmail.com

DOI: http://dx.doi.org/10.12775/BPTh.2015.023

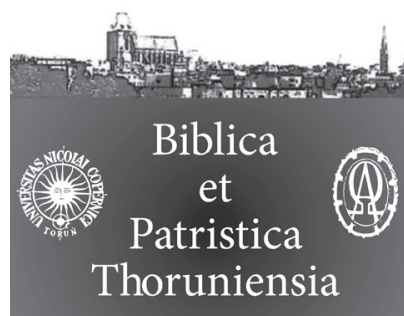

8 (2015) 4: 11-21

ISSN (print) 1689-5150

ISSN (online) 2450-7059

\title{
The Structure, Meaning, and Function of Josh 2 from an Aural Critical Perspective
}

\section{Struktura, znaczenie i funkcja Joz 2 ze słuchowo krytycznej perspektywy}

\begin{abstract}
The Rahab and spies story in the book of Joshua generated a great deal of studies. Many questions are left unanswered, or unsatisfactorily attended. What makes its parts come together into one? How does it operate within the book? These are some of the questions addressed in this short study of Josh 2. It aims to show that the "aural critical" reception of the narrative clarifies a bit more this chapter in its meaning and function. Indeed, it presents to its aural audience three circles organized around the three main characters (Joshua, the King of Jericho, and Rahab) as community leaders. Rahab's role provides the discerning principle for taking side with Yhwh's people. Thus, Josh 2 serves as a rationale for the course of action in the following episodes.
\end{abstract}

Streszczenie. Historia Rachab i szpiegów w Księdze Jozuego wygenerowała wiele badań. Wiele pytań pozostaje bez odpowiedz albo są niezadowalająco rozwiązane. Co sprawia, że jej elementy łączą się w jedno? Jak to działa wewnątrz księgi? Oto niektóre pytania skierowane w tym krótkim studium Joz 2. Artykuł ma na celu pokazać, że „słuchowo krytyczny” odbiór narracji wyjaśnia jeszcze bardziej ten rozdział w jego znaczeniu i funkcji. Rzeczywiście przedstawia swoim słuchaczom trzy kręgi zorganizowane wokół trzech głównych bohaterów (Jozuego, króla Jerycha i Rachab) jako liderów społeczności. Rola Rachab dostarcza zasadę, aby stanąć po stronie ludu YHWH. Tak więc Joz 2 służy jako uzasadnienie dla przebiegu działań w kolejnych epizodach.

Słowa kluczowe: Rahab; Jerycho; słuchowy krytycyzm; Jozue.

Keywords: Rahab; Jericho; aural criticism; Joshua. 


\section{Introduction}

Commentators have either considered Josh 2 problematic, at odd in its present context in the Joshua narrative, or lacking an internal unity. ${ }^{1}$ There are indeed reasons for that. This study would like to address the question of the meaning and function of this piece within the whole narrative. Before we engage this aspect of our research, the notion of "aural criticism" needs some clarification.

Biblical criticism has long operated from the point of view of "scribes," as such exegetes tried to reconstruct the compositional process of the text, or of "readers," by working on the esthetic of storytelling, and rarely from that of "listening audiences." From a historical point of view, the biblical text performance happened in an oral communication process. Reading the text aloud to a listening audience ${ }^{3}$ seemed to have been the mindset of writers/redactors who composed it. Bearing that in mind, the paper will try to show the careful knitting of the narrative fabric of Josh 2, obeying formal principles meant to facilitate a good aural reception of its message.

The first step will be to display the "aural structuring" of Josh 2, and then to overhear what the respective conversation partners have to say to each other. These steps will lead us to the function of the character that serves as the focal point of the story, and to the function of the story itself within the book. Such

1 For an overview on the state of the study of Joshua, see Ed Noort (ed.), The Book of Joshua (BETL 250; Leuven-Paris-Walpole, MA: Peeters 2012); on Josh 2, see Richard Nelson, Joshua. A Commentary (OTL; Louisville, KY: Westminster John Knox Press 1997) 36-52; Sarah L. Hall, Conquering Character. The Characterization of Joshua in Joshua 1-11 (LHB.OTS 512, New York/London, T\&T Clark, 2010) 28-45; José Luis Sicre, Josué (Pamplona: Editorial Verbo Divino 2002) 102-119; Trent C. Butler, Joshua 1-12 (WBC 7a; Zondervan 2014), 233-267; Thomas B. Dozeman, Joshua 1 - 12. A Translation with Introduction and Commentary (AYB 6B; New Haven \& London: Yale University Press 2015). The last three books provide a good overview of the literature and the main issues of the chapter.

2 See Paul Béré, "Auditor in fabula - la Bible dans son contexte oral : Le cas du livre de Ruth, Old Testament Essays 19/3 (2006) 1089-1105; we know that the biblical text operated in an oral cultural context, "wirft aber zunächst wenig Licht auf die Frage nach der konkreten Rezeption von oral vorgetragenen Texten im Hörvorgang," remarked Moisés Mayordomo-Marín, Den Anfang hören. Leseorientierte Evangelienexegese am Beispiel von Matthäus 1-2 (FRLANT, 180) 168.

3 See David Carr, Writing on the Tablet of the Heart. Origins of Scripture and Literature (Oxford: Oxford University Press 2005); Karel van der Toorn, Scribal Culture and the Making of the Hebrew Bible (Harvard University Press: Cambridge, MA/London,UK, 2007). 
an approach may help solve some of the riddles encountered while reading or listening to the final form of Joshua.

\section{The Aural Structure of Josh 2}

Previous proposals on the structure of this pericope have identified concentric structures ${ }^{4}$ three theatrical acts,${ }^{5}$ or a classic quinary scheme, ${ }^{6}$ to name but a few. In the end, the story of Rahab and/or the spies as heroes leaves the audience with unattended questions on its main theme, structure, function, and significance. In spite of the amount of literature on Josh 2, we still need to understand its shape. In providing a new approach to the story, I would like to underscore the importance of the hearers as a methodological concept and category.

The quest of the "aural structuring" of Josh 2 means the search for the way by which the listening audience received the text as it was read. Actually, passages like $\mathrm{Ne}$ 8:1ff or Lk 4:16ff clearly point to the need of working out the paths of the hearing community into the world of the text and its meaning. A hypothesis at play here is that the manner in which people communicated in the world of the text reflected the real experience of the audience. ${ }^{7}$ Therefore, the conversation between characters becomes a guiding principle to identify the nature of their relations, and the levels of communication between the reader and the audience. Conversation thus takes place in a bipolar mode. As we study Josh 2, we should find a conversation pattern that organizes the narrative flow.

When we ask, "who is talking to whom? What is s/he saying?" the result is a set of ten groupings of pairs in conversation, as the following chart shows ${ }^{8}$ :

4 See Klaus Bieberstein, Josua-Jordan-Jericho: Archäologie, Geschichte und Theologie der Landnahmeerzählungen Josua 1-6 (OBO, 143; Fribourg-Göttingen: Vandenhoeck \& Ruprecht 1995).

5 See Sicre, Josué (2001).

6 See Butler, Joshua 1-12 (2014).

7 See Béré, “Auditor in fabula," 1098-1100, where I have shown how the characters are organized around Ruth.

8 The direct quotation of the characters' words are mainly taken from the NRSV. 


\begin{tabular}{|c|c|c|}
\hline I. Joshua to Spies & v.1 & "Go, view the land, especially Jericho." \\
\hline II. someone to King & v. 2 & $\begin{array}{l}\text { "Some Israelites have come here tonight to search out } \\
\text { the land." }\end{array}$ \\
\hline $\begin{array}{l}\text { III. King to Emissaries } \\
\text { (message for Rahab) }\end{array}$ & v.3 & $\begin{array}{l}\text { "Bring out the men who have come to you, who } \\
\text { entered your house, for they have come only to search } \\
\text { out the whole land." }\end{array}$ \\
\hline $\begin{array}{l}\text { [Emissaries } \\
\text { to Rahab?] }\end{array}$ & & (Missing?) \\
\hline $\begin{array}{l}\text { IV. Rahab } \\
\text { to Emissaries }\end{array}$ & vv.4-5 & $\begin{array}{l}\text { "True, the men came to me, but I did not know where } \\
\text { they came from. }{ }^{5} \text { And when it was time to close } \\
\text { the gate at dark, the men went out. Where the men } \\
\text { went I do not know. Pursue them quickly, for you can } \\
\text { overtake them." }\end{array}$ \\
\hline V. Rahab to Spies & vv.9-13 & $\begin{array}{l}\text { "I know that Yhwh has given you the land, and } \\
\text { that dread of you has fallen on us, and that all } \\
\text { the inhabitants of the land melt in fear before you. } \\
{ }^{10} \text { For we have heard how Yhwh dried up the water } \\
\text { of the Red Sea before you when you came out of Egypt, } \\
\text { and what you did to the two kings of the Amorites } \\
\text { that were beyond the Jordan, to Sihon and Og, whom } \\
\text { you utterly destroyed. }{ }^{11} \text { As soon as we heard it, our } \\
\text { hearts melted, and there was no courage left in any } \\
\text { of us because of you. Yhwh your God is indeed God } \\
\text { in heaven above and on earth below. }{ }^{12} \text { Now then, } \\
\text { since I have dealt kindly with you, swear to me by } \\
\text { Yhwh that you in turn will deal kindly with my family. } \\
\text { Give me a sign of good faith }{ }^{13} \text { that you will spare my } \\
\text { father and mother, my brothers and sisters, and all } \\
\text { who belong to them, and deliver our lives from death." }\end{array}$ \\
\hline VI. Spies to Rahab & v.14 & $\begin{array}{l}\text { "Our life for yours! If you do not tell this business } \\
\text { of ours, then we will deal kindly and faithfully with } \\
\text { you when Yhwh gives us the land." }\end{array}$ \\
\hline VII. Rahab to Spies & v.16 & $\begin{array}{l}\text { "Go toward the hill country, so that the pursuers may } \\
\text { not come upon you. Hide yourselves there three days, } \\
\text { until the pursuers have returned; then afterward you } \\
\text { may go your way." }\end{array}$ \\
\hline
\end{tabular}




\begin{tabular}{|c|c|c|}
\hline VIII. Spies to Rahab & vv.17-20 & $\begin{array}{l}\text { "17 We will be released from this oath that you have } \\
\text { made us swear to you }{ }^{18} \text { if we invade the land and you } \\
\text { do not tie this crimson cord in the window through } \\
\text { which you let us down, and you do not gather into } \\
\text { your house your father and mother, your brothers, } \\
\text { and all your family. }{ }^{19} \text { If any of you go out of the doors } \\
\text { of your house into the street, they shall be responsible } \\
\text { for their own death, and we shall be innocent; but } \\
\text { if a hand is laid upon any who are with you in the } \\
\text { house, we shall bear the responsibility for their death. } \\
{ }^{20} \text { But if you tell this business of ours, then we shall } \\
\text { be released from this oath that you made us swear } \\
\text { to you." }\end{array}$ \\
\hline IX. Rahab to Spies & v. 21 & "According to your words, so be it." \\
\hline X. Spies to Joshua & v. 24 & $\begin{array}{l}\text { "Truly Yhwh has given all the land into our hands; } \\
\text { moreover all the inhabitants of the land melt in fear } \\
\text { before us." }\end{array}$ \\
\hline
\end{tabular}

Before moving forward in the analysis, the above table calls for some remarks:

- Joshua sends (שלח) the spies in secret (v.1), but someone (an unidentified person) reports to the king of Jericho the presence of spies from the Israelites (v.2). The narrative does not reveal the way the information reached the king. This silence should mean more than an esthetic craft of the story, or a suspense to trigger the curiosity of the audience.

- The King of Jericho sends (שלח) emissaries to Rahab, but they do not speak directly to her in the story. She simply responds to them as if she were overhearing the King (v.3), in order to redirect their attention. An inquisitive mind cannot but raise some questions: how did she get the message? or why did the narrator cut short the chain of transmission? There must be some reason.

- Rahab will send (שלח) the spies away back to Joshua who had sent (שלח) them to Jericho.

- The verb שלח marks off the three main characters, namely Joshua, the King of Jericho, and Rahab. These three are vested with authority over their respective communities.

- From a quantitative point of view, Rahab and the Spies sent by Joshua do occupy the center of the stage and get the attention of the audience by the length of their conversations (vv.9-13, 14, 16, 17-20.21).

- Finally, the inclusion looks evident: Joshua sends the spies (v.1) and they come back with a report (v.24). As noted by most commentators, 
they have not seen the land; they have not been outstanding spies. They remained in Rahab's house, which the narrator describes as located on the city wall (v.15). It implies the border of the city (land).

The conversation between the characters as reported above carries with it an inner logic which we can better underline by another chart ${ }^{9}$ :

\begin{tabular}{|l|l|l|l|l|l|}
\hline Characters & Joshua & $\longrightarrow$ Spies & Rahab $\longrightarrow$ Emissaries & \multicolumn{1}{c|}{ King } \\
of Jericho
\end{tabular}

The parallelism seems obvious: Rahab stands between the King of Jericho and Joshua, while her house set up on the city wall looks like a threshold. The physical position of the house could be saying something on her marginalized status. The chart once more provides some clue to the dynamics of the narrative. Two circles are in confrontation: Israel (Joshua and the spies) and Jericho (the King and his emissaries). The movement of the words exchanged (indicated by the arrows) clearly shows that Rahab cooperates with Israel's circle. But the formal evidence does not suffice to understand the function of the story in its context within the book. ${ }^{10}$ We still have to hear the conversations within the circles.

\section{Overhearing the Conversations}

As shown in the chart, the three main characters are heading three circles: Joshua and Israel circle, the King of Jericho and his circle, and Rahab and her circle. None of the three main personages meets another in the story. On one side, we have spies who bridge the Joshua and Rahab circles, and on another, emissaries

9 The arrows in the chart mean take different shapes according to the type of the conversation, but they always indicate the direction of the communication. In this case, the emissaries neither speak to Rahab, nor report to the King.

10 Other studies have emphasized the intertextuality of Josh 2 in relation to the Pentateuch, Judges, Samuel, etc. See for instance, Elie Assis, “The Choice to Serve God and Assist His People: Rahab and Yael," Biblica 85 (2004) 82-90. 
who create a link between Rahab's and the King of Jericho's circles. One could guess that this would have appeared in the mental visual scene of the aural audience, should they be hindered from hearing the respective conversation. What would they be hearing otherwise?

\subsection{Joshua's Circle}

The members of this circle are Joshua and the two spies. At the beginning of the story (v.1), one hears Joshua ordering the spies to "look at" (ראה) the land, especially Jericho. The waw here functions as explicative. The targeted place is the city. At the end (v.24), in the report, the spies tell Joshua that Yhwh has "given in our hands the whole land, and the inhabitants of the land are taken by fear." Before crossing the Jordan, therefore, Joshua is told that the people of Jericho are fearful. Knowing the state of mind of the enemy is important in a war situation. Given that the spies were not asked to go and ask Yhwh's will from a diviner before the war, where does their certitude on Yhwh's future action come from?

\subsection{The King of Jericho's Circle}

An unknown and unveiled character informed the King about the two spies from the Israelites who have come to search out the land (חפר). The message of the King to Rahab adds more to what he has heard: these men have come to "search out the whole land" (my emphasis). Rahab's response accepts the fact that the men came to her, but denies any further knowledge about their origin (where from) and destination (where to). She even urged them to move on quickly and pursue the men. Her refusal to cooperate is obvious as commented on by the narrator: she has first hidden the two men on her roof, and then addressed the emissaries. She did not want to give them over to the King. The audience cannot but be interested in knowing her reasons. We must therefore listen to the conversation between her and the men in house.

\subsection{Rahab's Circle}

The conversation takes the greatest portion of the story. The two partners are Rahab and the spies. The story mentions nobody else. Rahab speaks first to the spies. What she says will have an echo in the spies' report to Joshua: "I know that

11 The spies' report looks like a quotation of Rahab's longer speech to them (2:9-13). It could be a narrative technique to refer the audience to what they have heard. 
Yhwh has given you the land, and that dread of you has fallen on us, and that all the inhabitants of the land melt in fear before you." (v.9; cf. v.24). In our analysis of the conversation in the Joshua's circle, we were looking for the source of the information on Yhwh's future action. We have some hints in Rahab's (enigmatic) speech. Yhwh's past action at the Reed Sea and the fate of the two Amorite kings (Sihon and Og) threw the dread on the people of Jericho. These two actions served as a ground for God's future involvement.

The second fact that grounded Rahab's statement is her request of an oath from the spies, which would guarantee her family's survival when Israel invades Jericho. She got what she wanted on condition that she keeps things secret, gathers her family in her house, and ties the crimson cord in the window. Her goodwill takes her further, since she tells the men how to avoid the pursuers. Above all, the core fact remains the expression of her faith: "Yhwh, your God, is indeed God in heaven above and on earth below" (v.11). The alliance between Rahab and the spies is therefore based on her faith in Yhwh's powerful deeds, and the host's kindness. Rahab's leadership is consistently preserved throughout the story, ${ }^{12}$ because her circle is "the only meeting point of the two groups [i.e., Israel and Jericho], and her actions are fundamental to the success of one and the failure of the other. ${ }^{13}$ "

\section{Josh 2 within the Book}

Does this story bring anything important to the whole flow of the Joshua narrative? From the ongoing analysis, the answer should be affirmative. It prepares the aural audience to listen to the story on the crossing of the Jordan (Josh 3-4) as an echo to the crossing of the Reed Sea, and to understand its purpose and meaning. Should the (scribe) reader skip Josh 2, I believe that the symbolic function of Jericho and Ai (Josh 6-8) may not be clear to the audience. The link between these two cities is not only paralleled with the two Amorite kings, Sihon and Og (see 2:10); there is more to it: Joshua approached them the same way $(2: 1 ; 7: 2-3)$, and Yhwh promised to treat Ai as he did with Jericho $(8: 2)$. Thus, those who are in Canaan will in turn hear about the crossing, and the two cities (see the recurring expression: ... כשמע 5:1; 9:1;10:1;11:1)

Rahab expressed her faith in the Israelite God, Yhwh, and then had the spies swear (שבע, 2:12) in Yhwh's name, and by so doing was spared and

12 Nelson believes that "Rahab is in firm control of the first two dialogues, but that the spies take control of the conversation in the third", Joshua, 40.

13 Nelson, Joshua, 40. 
allowed to live in the Land (6:22-23). For the audience, she became a landmark in the story. One understands how the Gibeonites made up their story, and saved their life through an account on what happened before the people entered the land $(9: 9-10 ; 9: 18-20$; see $2: 10)$. The fact that their story ignored what happened after the crossing of the Jordan put them on the same level of knowledge as Rahab. It meant therefore, as they had planned, that they came from afar, unlike "all the kings of the Amorites who were beyond the Jordan to the west" $(5: 1 ;$ cf. 9,7; 11,19). They too saved their life thanks to an oath taken by "the leaders of the congregation" (שבע, 9:15). Further in the book, Caleb was granted full right in the land because Moses swore (שבע, 14:9) he would share the inheritance of the Land.

These links evidence the necessary background function of Josh 2. Rahab plays the role of the information provider, from a believer's point of view. Indeed, human views are short sighted as in Josh 7 when disobedience to divine will obscured the mind of the spies. They did spy out the land of Ai (7:2), but the human strategy did not bring about victory. Such intertwinements of the episodes in the book makes it stand as a whole for the audience. We need to investigate more.

\section{Concluding remarks}

From the outset, this paper aimed at finding out the inner knitting of the Rahab story, and its meaning and function in the book of Joshua. Former methods, be they synchronic or diachronic, pointed out some difficulties that did not help readers make sense of this marvelous tale within the book. The use of "aural criticism" cleared to some extent the way, I believe, for a new perspective on the story and its relation to the crossing of the Jordan, to Jericho and Ai, to the Gibeonites, and to Caleb. Although many more intertwined episodes still need to be brought to light, some findings can be summed up to conclude this short study.

We found that ten pairs of conversation instances run through Josh 2, and have served to shape the narrative flow for the aural audience. They can be organized in three circles at three distinct places (Israel, the house on the city wall, and Jericho) around three key figures (Joshua, Rahab, and the King of Jericho), singled out by the verb שלח. This verb characterized the main characters as leaders with people under their responsibility. Rahab functions as a referee between the other two circles. ${ }^{14}$ The peak of the story for the aural audience

14 The historical meaning of these three circles and the role of the "Rahabites" should be further investigated. Some suggested the view that the "landless Israelites, their peasant 
appeared to be the conversation between Rahab and the spies, in the former's space (her house). In the end, Rahab has chosen to put herself and her family under Yhwh's wings. Her words and attitude thus became the reference point of the following episodes.

\section{Bibliography}

Assis, Elie, "The Choice to Serve God and Assist His People: Rahab and Yael," Biblica 85 (2004) 82-90.

Béré, P., Le Second Serviteur de Yhwh: Un portrait exégétique de Josué dans le livre éponyme (OBO 253 ; Fribourg-Göttingen : Academic Press - Vandenhoeck \& Ruprecht, 2012).

Béré, Paul, "Auditor in fabula - la Bible dans son contexte oral: Le cas du livre de Ruth, Old Testament Essays 19/3 (2006) 1089-1105.

Bieberstein, Klaus, Josua-Jordan-Jericho: Archäologie, Geschichte und Theologie der Landnahmeerzählungen Josua 1-6 (OBO 143; Fribourg-Göttingen: Vandenhoeck \& Ruprecht 1995).

Boneva, Krassimira, «La puissance du croire dans létablissement d'un contrat selon le livre de Josué (chapitre 2)», Sémiotique Biblique 101 (2001) 42-49.

Briend, Jacques, «Une épopée de fiction: Josué 2.6-12», dans : Comment la Bible saisitelle l'histoire? (Lectio Divina 215; Paris, Les Éditions du Cerf, 2007) 57-71.

Butler, Trent C., Joshua 1-12 (WBC 7A; Grand Rapids, MI: Zondervan 2014).

Carr David, "Mündlich-Schriftliche Bildung und die Ursprünge Antiker Literaturen," in H. Utzschneider-E. Blum (ed.), Lesearten der Bibel. Untersuchungen zu einer Theorie der Exegese des Alten Testaments (Stuttgart: Kohlhammer 2006) 183-198.

Carr, David, Writing on the Tablet of the Heart. Origins of Scripture and Literature (Oxford: Oxford University Press 2005).

Dozeman, Thomas B., Joshua 1 - 12. A Translation with Introduction and Commentary (AYB 6B; New Haven \& London: Yale University Press 2015).

Hall, Sarah L., Conquering Character. The Characterization of Joshua in Joshua 1-11 (LHB.OTS 512, New York/London, T\&T Clark, 2010).

Horsley R.A., Text and Tradition in Performance and Writing (Biblical Performance Criticism 9; Cascade Books 2013).

Mayordomo-Marín Moisés, Den Anfang hören. Leseorientierte Evangelienexegese am Beispiel von Matthäus 1-2 (FRLANT, 180) 166-170.

Nelson, Richard, Joshua. A Commentary (OTL; Louisville, KY: Westminster John Knox Press 1997).

descendants, and the clan of Rahab stand together in a social sense as marginalized groups over against Jericho's king, who represents the centralized power of the royal establishment," Nelson, Joshua, 44. 
Noort, Ed (ed.), The Book of Joshua (BETL 250; Leuven-Paris-Walpole, MA: Peeters 2012).

Sicre, José Luis, Josué (Pamplona: Editorial Verbo Divino 2002) 102-119; Trent C. Butler, Joshua 1-12 (WBC 7a; Zondervan 2014).

Toorn, Karel van der, Scribal Culture and the Making of the Hebrew Bible (Harvard University Press: Cambridge, MA/London, UK, 2007). 